\author{
Katarzyna SkIERT-AndRZEJUK \\ Collegium Civitas \\ ORCID: https://orcid.org/0000-0003-4451-5092
}

\title{
Status and Role of the Young Generation in the Social and Political Space of Georgia
}

\section{Status and Role of the Young Generation in the Social and Political Space of Georgia}

\section{Abstract}

The aim of the paper is to examine the status and role of the young generation in the social and political space of Georgia. The paper states that the young generation of Georgians does not enjoy high social status, even though the young can and probably will constitute the future elite of Georgian society. To analyze this research problem, I have used a number of research methods based partly on secondary sources. Three main research methods have been used in the study-desk research method, comparison, and the statistical method based on secondary data that have been extracted from the Caucasus Research Resource Center (CRRC) database. The paper is a snapshot of studies on the theory of notions of "status" and "role", and it presents the work of Polish scholars. Moreover, the paper opens the door to further research on the young and democracy in Georgia. The studied issue is essential for analyzing the perception of democracy and democratization among the generations in Georgia. The paper is part of a series of articles on the opinion of the young generation of Georgians about democracy and democratization.

Keywords: status, role, young Georgians, young generation, Georgia, democracy, democratization, Georgian society 


\section{Статус и роль молодого поколения в социально-политическом пространстве Грузии}

\section{Аннотация}

Целью статьи является исследование статуса и роли молодого поколения в социально-политическом пространстве Грузии. Заключение исследования состоит в том, что молодое поколение грузин не имеет высокого социального статуса, хотя молодые могут и, вероятно, составят будущую элиту грузинского общества. Для анализа исследовательского вопроса был использован ряд методов, частично основанных на вторичных источниках. Статья представляет собой краткий обзор теории понятий «статус» и «роль», и знакомит с результатами работы польских ученых. Данная статья открывает также двери для дальнейших исследований молодежи и демократии в Грузии. Статья имеет важное значение для анализа восприятия демократии и демократизации поколениями в Грузии.

Ключевые слова: статус, роль, молодые грузины, молодое поколение, Грузия, демократия, демократизация, грузинское общество

\section{Preliminary Remarks}

Georgia's political, economic, and cultural environment has changed over the past three decades. First of all, a new generation of Georgians was born ${ }^{1}$ that is currently facing many challenges related to social, political, and cultural

1 According to A. Sosnowski the youth can be defined as people in the age group 14/15 to $25 / 26$ and their separation from some of the modern societies is a historical one. The author notes that some youth sociologists postulate either to lower the limit for the selection of the youth category to 10/12 years old, which is associated with biological acceleration, or try to increase the upper limit to $30 / 35$ years old, which in turn would be the result of extended education. On the contrary, in accordance with the definition of "the youth" by the United Nations-young people as a social category are people aged 15/16 to 30 years old. Extending the youth stage is associated with biological acceleration (earlier reaching physical and sexual maturity); increasing the number and participation of young people in the social structure; extending the period of gaining economic, social and professional independence; According to V. Papava, the specificity of such a transformation in the post-Soviet area was the transformation from homo sovieticus into homo transformaticus and homo oeconomicus. According to the author, one more transformation is taking place in the Georgian society into paradox generation, i.e., the youngest generation born after 2000. Homo oeconomicus, millennials, generation Y, bborn in 1990-2000, paradox generation, generation Z; According to V. Papava homo oeconomicus (Papava, 2002, p. 796-805). 
life, one of which is the democratization of the state and the overlapping globalization and westernization. Opinions of the young generation on democracy and attitudes towards building a civil society are a particularly important issue, because young people in political processes taking place in democratic countries (as well as in totalitarian and authoritarian systems) constitute a significant and valuable part of society. This social group is considered to be the most inspiring in the nation as a whole.

This paper aims to examine a part of society that is the young generation. Due to the terminological grid, literature, and methodology used, which in the case of analyzing status and role are extensive, the study itself is a snapshot of studies on the status and role of young Georgians in the society, and it also contributes to further in-depth research. The paper is part of a series of articles on the opinion of the young generation of Georgians about democracy and democratization.

This paper can be considered crucial for several reasons. First, a study on the status and role of the youth in society is relevant to understanding the complexity of Georgian society. Second, some of the young in the near future will have a chance to constitute the future new elite of Georgia. Third, the paper is a contribution to further research on the status and role as well as on the involvement of young people in socio-political life. Fourth, due to the current democratization of Georgia the results of these studies may contribute to further research on democracy and understanding democracy from the "bottom-up." Fifth, the studied issues fill the research gap on young people in the post-Soviet states and young people in Georgia.

Three main research methods have been used in the study-desk research method, comparison, and the statistical method based on secondary data. The desk research method has been used in analyzing the definitions and studies on the notion of "status" and "role." Moreover, the theoretical framework analyzed presents, among others, the work of Polish scholars. The statistical method is based on the secondary data that have been extracted from the Caucasus Research Resource Center (CRRC) database- the Online Data Analysis tool. I have compiled the results of these studies by year, analyzing only young people aged 18-35 as people representing the young generation of Georgians. Yet, in other analyses I have used the age group 18-35/36 as stated in footnote 1. The comparison has helped to analyze the statistical results over the years. 
There are research limitations in the study, namely technical limitations. Due to the extensive literature on the subject, I have used part of the research on the notion of "status" and "role." To organize all the research on these concepts, a separate article would be needed. Yet, to implement the issue of the young I have examined and organized a snapshot of the studies on the status and role of young Georgians in the society.

\section{Theoretical Framework and Discussion}

The internal diversity of societies is influenced by many factors such as ethnic origin, sex, age, education, etc. All these elements make up the social status (social position) of an individual in a given society. P. Sztompka defined the social status in four dimensions: normative (institutional); consciousness (as certain beliefs, as positional mentality ${ }^{2}$ ); interactive (the sense of social belonging understood by interaction channels) and related to specific interests (e.g., access to goods, prestige, wealth) (Domański, 2009).

The structure and hierarchy of social statuses translates into the social structure (social stratification). H. Domański defines social stratification as a structure built on differentiation in terms of social privileges (statically), and as a process of placing individuals in a hierarchy (dynamically) (Domański, 2004, p. 36-37).

The stratification may be various forms of hierarchy, divisions, distances and barriers, understood as objective phenomena, for example inequalities resulting from income or the prestige of a profession. All behaviors and attitudes that manifest superiority or result from a sense of inferiority are also stratified, as exemplified by social identification, i.e., with the working or middle class, prestige hierarchy and other aspects of individual consciousness, as long as they create relatively permanent structures. Social stratification can be measured in terms of the availability of up to five basic social resources, such as power, money, prestige, education, and health. Moreover, it means that in the structure of each society some designated classes are higher than others-that is, certain individuals occupy a designated place, revealing social

2 That is, evaluation of one's position in society. 
inequalities depending on their professional status, education, or received income (Skarżyńska, 1981).

The problem of social position was also taken up by M. Weber, who recognized wealth, prestige, and power as crucial elements constituting social stratification. According to him the factors influencing social status may be convergent (people who are rich, influential, and respectable at the same time) or divergent (rich people may have enormous fortunes, but they will not gain greater public approval) (Waters, Waters, 2015).

The concept of "social structure" emphasizes the stability and unchanging of certain aspects or dimensions of the functioning of society. Each social position is associated with power, privileges, social prestige, access to information, knowledge, or property; the availability of these socially important goods varies for different social positions. The highest positions give increased access to the most valued goods, whether tangible or intangible, which are insufficient to be available to everyone. The differentiation of social positions within the social structure creates a social hierarchy. According to G.C. Homans, social positions create "social classes," which are distinguished on the basis of economic property relations (Homans, 1961, p. 247).

Social status is related to a specific role that an individual has or should play in society. And the very notion of "role" is defined as a set of rights and obligations resulting from taking a specific position in society ${ }^{3}$. The notion of "social role" was introduced by G. Mead in the framework of social psychology, and developed by R. Linton in the framework of sociology. According to them, the role that an individual plays in society depends on several factors. Moreover, the social role depends on social and family expectations in the context of a specific cultural and ideological framework (Spielberger, 2004).

According to J. Szmatka, "the social role is the most elementary mediating structure that links individual and social phenomena, and the individual with society" [translation] (Szmatka, 1980). The literature on the subject also distinguishes the following expectations towards a specific social role:

1. on the part of the norms assigned by a given society ${ }^{4}$;

3 "Role" is also identified with the notion of "function" in the functionalist paradigm.

4 The normative role, as noted by E.W. Bielajew and D.N. Szalin, in this approach is the fact of subordinating the behavior of an individual to certain laws, social norms, rules of 
2. on the part of other individuals who expect specific behavior from each other;

3. on the part of those interested in the way they perform the role (Olubiński, 1990, p. 269).

Moreover, three components affecting the role of an individual in society should be distinguished - the assigned role, the subjective role (the emphasis here is on the subjective interpretation of social expectations and situations), and the role performed (the main emphasis is on the behavioral aspect of the individual's treatment of the role). The above elements are related, however, the ultimate role of an individual depends on certain social and cultural patterns and the role they want to perform (Olubiński, 1990, p. 270).

Determining the role in society is directly related to the "marking" and "labelling" of an individual. This means that a group assigns certain skills and characteristics to an individual so that he or she performs a specific function within that group-whether he / she wants to or not. Due to frequent social pressure and permanent "labelling," the individual consciously or unconsciously assumes a designated role in society, meeting their expectations. The mechanism of entering into a specific social role depends on the content of the role, i.e., the taking over by an individual of certain values and social norms (Turner, 1985, p. 377-394). Thus, the content of the role reflects the system of values, ideology, and cultural framework of a given society.

F. Znaniecki defined the social role as a system of:

(...) normative relations between an individual and a part of his / her social environment. Such a system designates that part of the environment, that 'social circle' with which the individual, as a 'social person, is to be normatively connected; one conditions 'social self', that is, the image of what one should be for others and for oneself in a given role as a physical and mental being; one establishes social status, that is, a set of rights that a given social circle is to grant them; and determines its 'social function, that is, a set of duties the performance of which may be required by a given circle. The roles played by different individuals in

coexistence in a group as stated. In other words, the individual inscribes his / her behavior within certain frames or barriers, previously established by society (Bielajew, Szalin, 1979). 
a certain community overlap; the dependence of other roles on a given role determines its social significance [translation].

F. Znaniecki divides the role into (Znaniecki, 1984, p. 530-531):

1. Role-demand - the role of an individual is determined by social expectations and norms (Znaniecki, 1971);

2. Role-concept - the role of an individual is influenced by both the expectations and social norms and the behavior of the individual;

3. Implemented (innovative) role - the role is influenced by an individual's perception of the assigned social role.

\section{The Social Status of the Young Georgians}

In this article, the social status of the young generation of Georgians will be determined by the availability of five basic social resources: power, money, prestige, health, and education, which are understood as:

1. Access to power - it will be considered in the context of the number of young people participating in it;

2. Money - in the context of the amount of earnings of young people;

3. Prestige ${ }^{5}$ - as a result of respect, lifestyle, profession.

4. Education - in the context of the number of young people with higher education;

5. Health - measured on the level of self-esteem in the context of physical and mental health.

When analyzing the current organizational structure of the Georgian parliament in terms of access to power by the young generation (people up to $35 / 36$ years of age), one can see a small share (5.3\% of all members of the

5 According to H. Domański: “(...) There are different shades of subjective importance of prestige, they manifest themselves in various circumstances, they are subject to changes and cannot be measured on a single scale (...)" [own translation]; "Prestige is a vast sphere of judgments (...) It is assigned to other people for their intelligence, knowledge, good appearance, social roles, positions, and successes in life (...) Prestige is difficult to grasp because one cannot see it directly (...)" [translation] (Domański, 2012). 
parliament) of this group of people. ${ }^{6}$ Currently, the following members of parliament are: Sopio Kiladze (born in 1984; Georgian Dream-Democratic Georgia), Shavla Kiknavelidze (born in 1987; Georgian Dream-Democratic Georgia), Irakli Mezurnishvili (born 1985; Georgian Dream-Democratic Georgia), Savalan Mirzoev born in 1986; Georgian Dream-Democratic Georgia); Anri Okhanashvili (born in 1985; Georgian Dream-Democratic Georgia), Tsotne Zurabiani (born in 1984; Georgian Dream-Democratic Georgia), Savalan Mirzoev (born in 1986; Georgian Dream-Democratic Georgia); Tsotne Zurabiani (born in 1984, Georgian Dream-Democratic Georgia). ${ }^{7}$

Within the executive branch of the Council of Ministers ${ }^{8}$, the youngest member of the Cabinet is Irakli Garibashvili, the Minister of National Defense, born in 1982, who is no longer included in the younger generation. ${ }^{9}$

Other categories of access to power include the participation of young people in the judiciary ${ }^{10}$. When analyzing Georgian courts, they are divided into common courts (the Supreme Court, courts of appeal, and regional courts) and the Constitutional Court of Georgia ${ }^{11}$. There are no people under the age of 36 in the current composition of the judges of the Supreme Court and the Constitutional Court.

Moreover, I have measured access to power through the involvement of young people in power structures, i.e. in the context of youth cooperation in the framework of initiatives organized by the Parliament of Georgia. One such initiative is the "Open Parliament" competition dedicated to students

6 According to the Georgian Constitution, people who have reached the age of 25 and have lived in Georgia for at least 10 years may become members of the parliament.

7 The vast majority are parliamentarians born in the years 1970-1980. After 1980, it was 17.3\% of all members; Parliament of Georgia, http://www.parliament.ge/en/.

8 According to the Georgian Constitution, a person who is 40 years of age or older can become a president and a person who is 35 years of age or older can become a judge of the Constitutional Court of Georgia.

9 Participation in local government authorities has not been analyzed due to research limitations related to the lack of literature and other data; Government of Georgia, http:// gov.ge/index.php?lang_id=ENG.

10 Persons over 30 years of age according to the Constitution of Georgia may become judges; http://www.parliament.ge/ge/ajax/downloadFile/32381/mosamartleta-danishvna.

11 The analysis of district and appellate judges is not possible due to the research limitations related to the lack of literature and other data. 
and pupils - it was organized by the Georgian Parliament with the support of the European Union (EU), the United Nations Development Program (UNDP) and the Institute for the Development of Freedom of Information (IDFI). Its purpose was to raise the awareness of young people and to present the ideas developed and selected for the Open Parliament Georgia Action Plan. As part of the third edition in 2018/2019, the winners of the competition presented their ideas to the Permanent Council for Open and Transparent Management and its Consulting Group (IDFI, 2018-2019) ${ }^{12}$.

I have analyzed the category of money using the monthly earnings indicated by the respondents of the study by the Caucasus Research Resource Center (CRRC) $)^{13}$ compared to the youth's recognized minimum monthly wage that would provide the basis for a "normal life"14 (Figure 1 and 2).

The presented data allow to state that young Georgians gain relatively low earnings compared to other age groups. Every third person aged 18-35 has no income, and nearly one in five earns less than USD 100 a month. At the same time, the financial expectations of young people in this age group are very high, with nearly $40 \%$ of respondents expecting a salary above USD 801 , and only $5 \%$ allowing for a salary of USD 250 or less. Older people, 56 years old and more, indicate a much better financial situation in almost half, with earnings in the range of USD 51-100 per month. In the age group of 36-55, similar indications can be observed. Concluding from the data above, people aged 36-55 earn the most, while young people mostly do not work or earn the national average of USD 372 per month (GDP per capita is USD 4,469.20) (Trading Economics).

12 The winners of the youth competition - Rusudan Mgeladze, Kalenika Uridia and Shalva Dekanozishvili. Their ideas were endorsed by the Permanent Council on Open and Transparent Management and will be reviewed during the preparation of the third Open Parliament Action Plan for 2018-2019. IDFI, https://idfi.ge/en/ contest_winner_youth_your_idea_for_open_parliament.

13 Caucasus Research Resource Centers (CRRC) is a network of research, resource, and training centers established in 2003 in the capitals of Armenia, Azerbaijan, and Georgia, to enhance social science research and public policy analysis in the South Caucasus; https:// caucasusbarometer.org/en/about/.

14 In a survey conducted by the Caucasus Barometer, the phrase "normal life" was used to mean "live a life with dignity" The issue of accumulated assets was not included due to the research limitations related to the lack of data. 
PERSINC: Personal income last month

by AGEGROUP: Age group (\%)

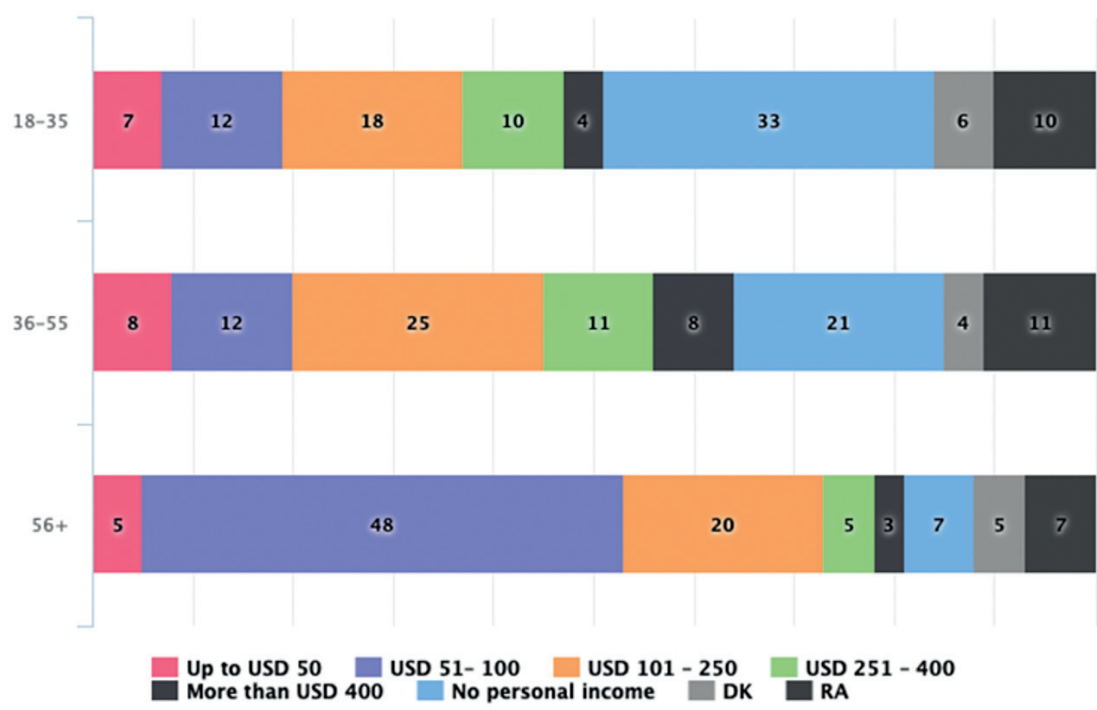

Figure 1. Personal Income in the Last Month (in USD, by Age, in 2019) Source: Caucasus Research Resource Center 2019.

MININCR: Minimal monthly income for normal life by AGEGROUP: Age group (\%)

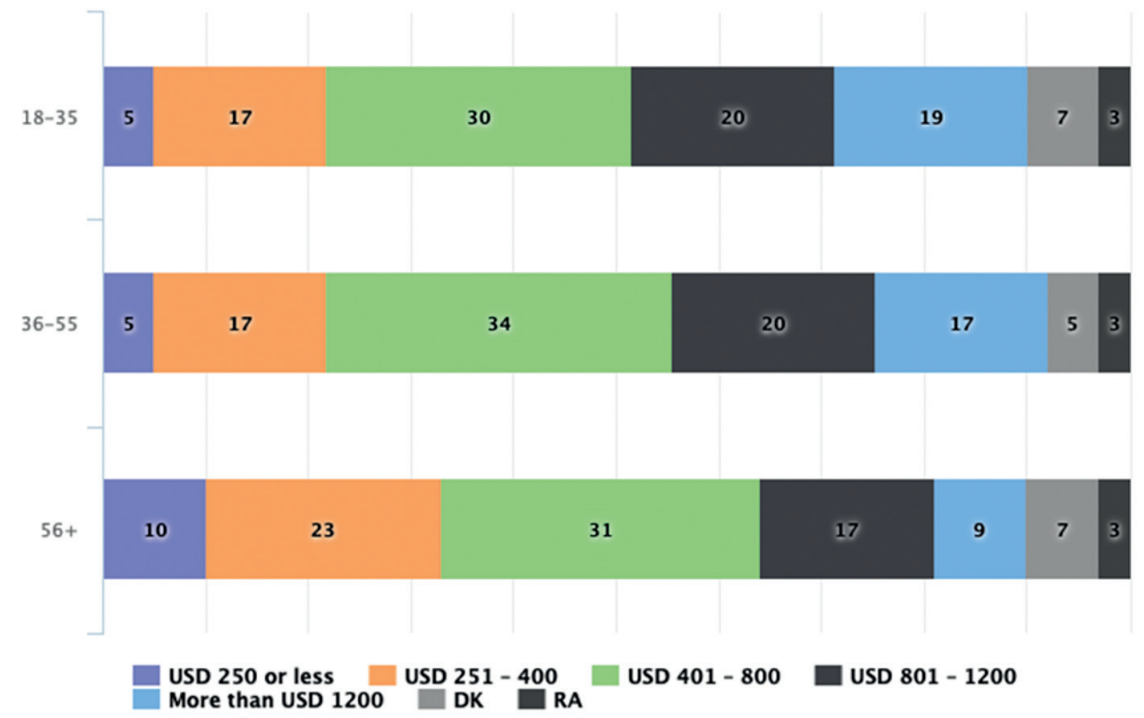

Figure 2. Minimal Monthly Income for Normal Life (in USD, by Age, in 2019) Source: Caucasus Research Resource Center 2019. 
According to a 2016 research by the Friedrich-Ebert-Stiftung Foundation, $62 \%$ of the surveyed young Georgians ${ }^{15}$ were financially supported by their parents. It was found that financial independence was more common among young people living in Tbilisi, where 35\% of respondents claimed that they lived independently, while only $27 \%$ of the residents of other cities were in a similar situation. The same research shows that $96 \%$ of respondents aged 14-18 were dependent on the family, as well as $64 \%$ of those aged 19-24, and $33.5 \%$ of respondents aged 25-29 (Friedrich-Ebert-Stiftung Foundation, 2016).

Prestige was measured using the "prestigious professions" (Global Teacher Status Index, 2018). According to the Global Teacher Status Index from 2019, a doctor, business administrator, engineer, policeman, nurse, accountant and school and university teachers are considered to be the most prestigious professions, and the least are street sweepers and dustmen (UNHCR Report 2008).

Figure 3 shows that a small number of young people work in sectors in which there are professions considered to be prestigious. Only $6 \%$ of young people found employment in the area of health and social work. A small number of young people work in the media $-7 \%$, and $10 \%$ in the public, administration, and judiciary sectors. The employment situation of young people does not differ significantly from that of people representing other age groups, with the exception of the agricultural and educational sectors, where older people take up jobs to a greater extent.

The education of young Georgians was presented in terms of the percentage of people undertaking higher education. According to the data of the National Statistical Office of Georgia from 2019, people aged 14-34 accounted for $25.81 \%$ of the total population, i.e., 960,800 people. At the same time, 152,776 people studied in Georgia in the same year at higher education, including doctoral studies, which in turn accounted for $15.9 \%$ of all young

15 The study included adolescents aged 14-29 using the questionnaire technique, face-to-face interviews and discussions in focus groups. The study was conducted from May to June 2016. 1,200 face-to-face interviews and 24 group discussions were conducted nationwide (Friedrich-Ebert-Stiftung Foundation, Generation in Transition: Youth Study 2016). 
WORKSEC: Sector of working

by AGEGROUP: Age group (\%)

WORKSEC: The question was asked to the respondents who were employed

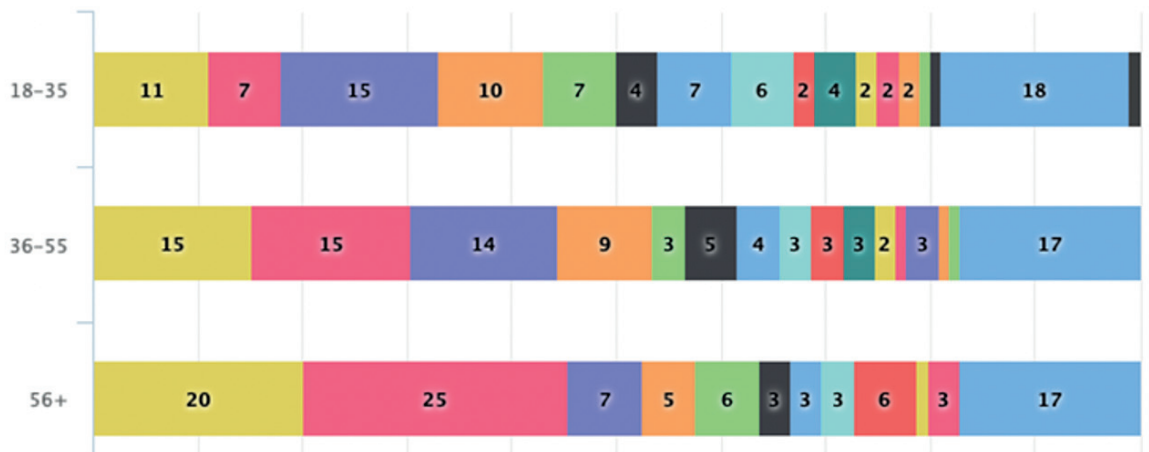

Education Agriculture, hunting, and forestry
Wholesale and retail trade, repair of motor vehicles, motorcycles and personal and household goods
Government, public administration and defense Construction
Transport, storage, communication Hotels, restaurants, or cafes
Healthcare and social work Manufacturing Minancial intermediation / Banking
Electricity, gas, or water supply Mivil society / NGOs Mass mediaing and quarrying
Real estate, property- and pent-related activities Mishing Other
RA

Figure 3. Sector of Working (by Age, in 2019)

Source: CaucasusResearch Resource Center 2019.

people (15-34 years old). It is also worth mentioning that in the 2019/2020 academic year, $64 \%$ of Georgian students studied at the first and second cycle level of education at public universities, and $36 \%$ at private universities. In the case of $\mathrm{PhD}$ students, $77 \%$ of them chose public universities, and only 23\% private ones (Georgian National Statistics Office, 2019). The total number of people studying in Georgia in 2019 broken down by age groups is shown in Figure 4.

In addition, the 2019 CRRC research on the level of education indicates that the majority of people who graduated from universities are those in the 36-55 and 18-35 age groups (Figure 5).

Research conducted in 2019 by the CRRC showed that the majority of young people consider their health to be satisfactory. Young people aged $18-35$ describe their health condition as good, at almost $50 \%$, and $14 \%$ of them as very good. Only $2 \%$ of respondents in this age group admit that 


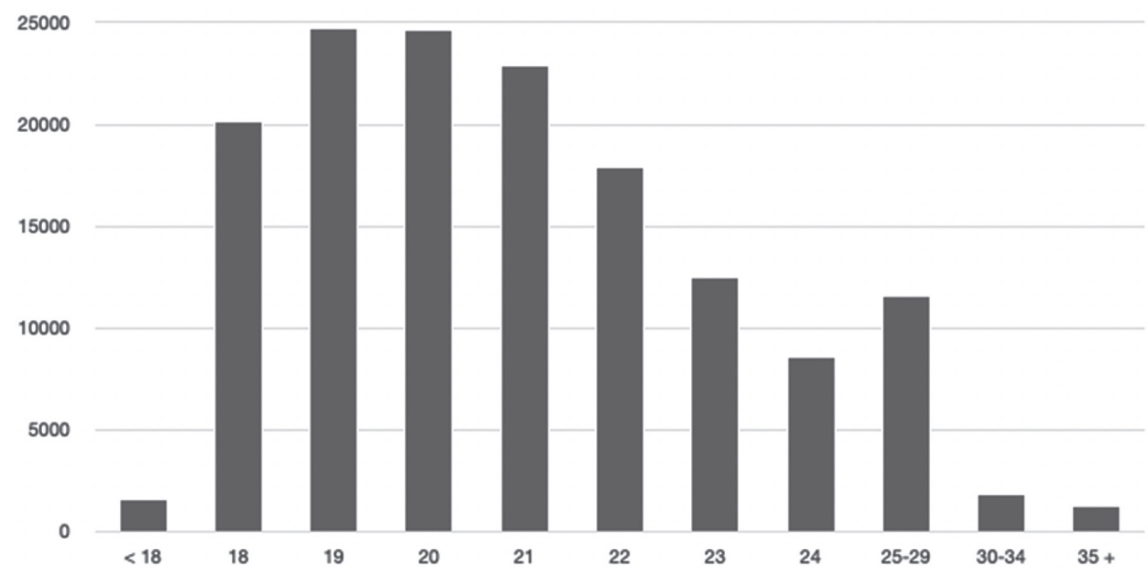

Figure 4. Total Number of Students by Age (in 2019)

Source: Georgian National Statistics Office, Geostat.ge.

AGEGROUP: Age group

by RESPEDU: Highest level of education you have achieved (\%)

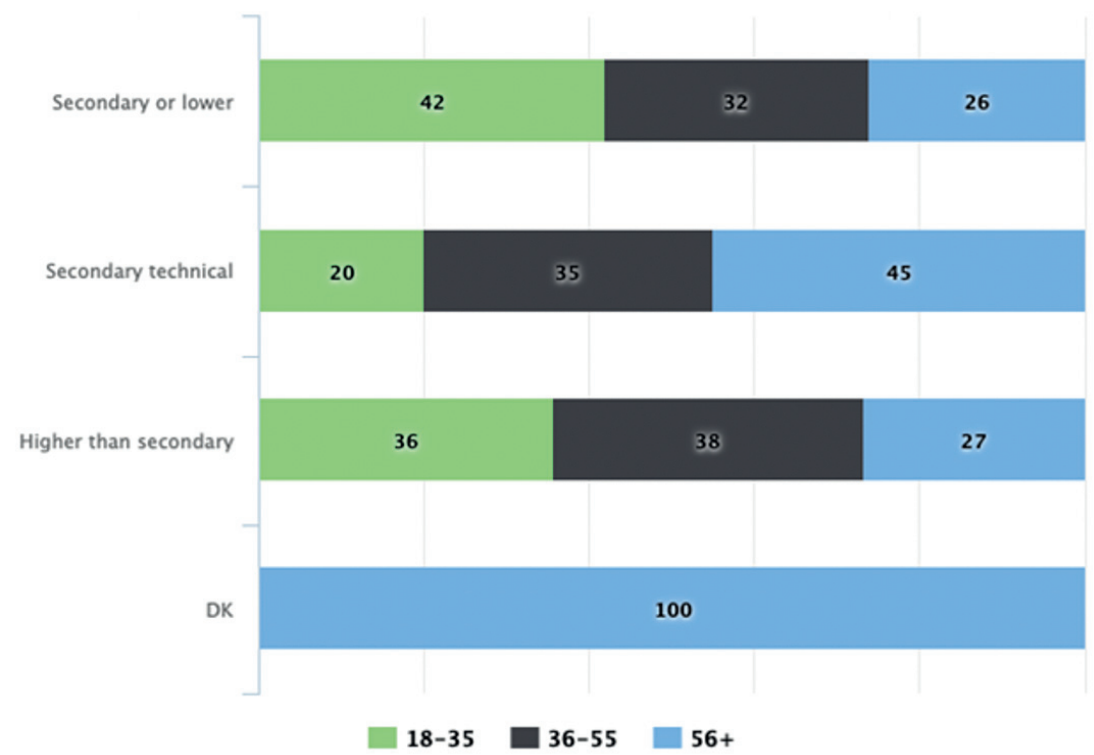

Figure 5. "Highest Level of Education You Have Achieved" (by Age, in 2019) Source: Caucasus Research Resource Center 2019. 
their health condition is unsatisfactory (Figure 5). According to the World Health Organization (WHO), whether people are healthy or not depends, among other things, on the place of residence, environment, genetics, income, level of education, relationships with friends and family. Access to and use of healthcare services, on the other hand, often has a smaller impact. WHO indicates that higher income, age, and higher education are associated with better health - the greater the gap between the richest and poorest people, the greater the difference in health (World Health Organization). Thus, analyzing Figure 6, it can be concluded that the satisfactory health condition of young people was, among other things, the result of not only their age, gender, but also their education.

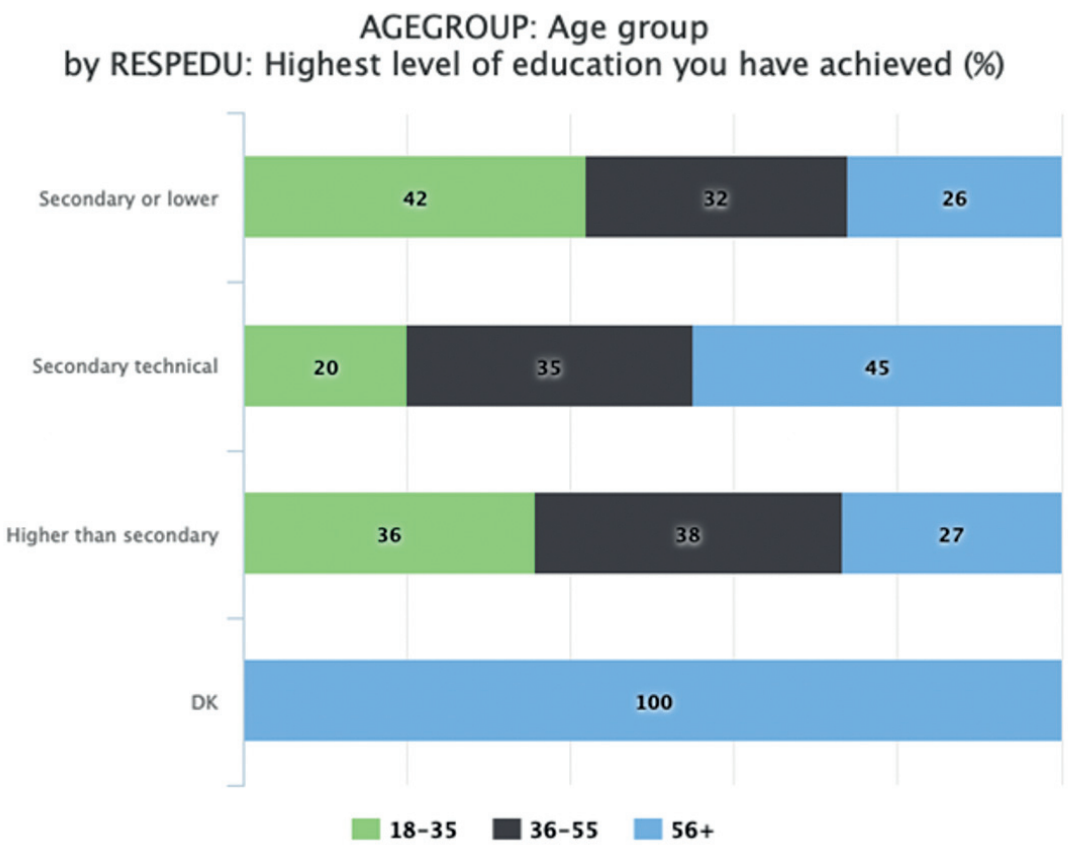

Figure 6. "How Would You Rate Your Health?" (by Age, in 2019)

Source: Caucasus Research Resource Center 2019. 


\section{The Role of Young Georgians in the Society}

According to F. Znaniecki's study, the role can be analyzed by three components, two of which will be discussed ${ }^{16}$ :

1. Role-demand-defined in the context of the expectations of Georgian society, including the family, towards the young generation;

2. Implemented role-showing how young people understand their role. Before the Rose Revolution, it was recognized that the role (role-demand) of young people was primarily to engage in socio-political transformations of the state. ${ }^{17}$ Currently, the role assigned to young people is to a greater extent their participation in economic life, especially in the tourism and energy sectors, the most developmental sectors and the most profitable sectors for Georgia. Tourism has a significant impact on overall economic development, and Georgian youth may have reason to stay in their regions and even return from Tbilisi. Young people in the Samegrelo-Zemo Svaneti and Kakheti regions believe that the tourism sector can create jobs, provide better income, and economic prosperity ${ }^{18}$. According to R. Teipelke and L. Lambert, young practitioners and specialists in the field of territorial development in Asia, the role of young people in the territorial development of Georgia should not be limited to the idea of opening a family quarters or a boarding house, which is a particularly common small business in Georgia. Young people can work as tour guides if they have the necessary local knowledge combined with language skills. With tourism growing in popularity, young Georgian app developers and web designers can double the customization of web services for travelers and travel service providers, including customized websites and social media marketing campaigns. Another sector related to the tourism

16 The role-concept will not be analyzed due to research limitations related to the lack of literature; and because of the concept itself, which implies subjective/individual issues related to the subconscious.

17 Civil society had a significant influence on the Rose Revolution and its major changes. One of the most notable effects was the brain drain from civil society to government.

18 In 2016, foreign tourists generated \$ 1.8 billion in the country, an increase of $11 \%$ compared to 2015. Currently, tourism accounts for 7\% of GDP, and its share is growing every year. In 2019, the income from tourism was \$3,051,424,548. 
aspect where young people can find work is agriculture, as visitors are interested in locally sourced, ecologically sustainable products (Hermann, 2018).

The role of the young generation in the development of the energy sector concerns their participation in creating new initiatives and supporting the old ones, which are one of the areas of cooperation within the Eastern Partnership. As part of supporting the role of young people in the development of the energy sector, including hydropower and wind, organizations such as the Association of Young Energy Professionals in Georgia (Association of Young Professionals in Energy of Georgia, n.d.) were established. The Association as a non-profit organization popularize energy policy issues among the public and support the organization of projects and initiatives related to the energy sector through research, education and consultations; hydropower conferences for young HIPP leaders organized by the Tbilisi International Economic School of Economics and the ISET Institute, which provides independent policy research and training (ISET Policy Institute, n.d.). Support for the development of the energy sector based on the young generation of Georgians was also provided by American organizations. According to J. Kelly, head of the US Bureau of Environment and Energy in the Caucasus, “(...) several large projects [in Georgia], one of which was a special program for students of the energy sector. As a result of this project, we already had 70 graduates, and currently twenty-five students are participating in the program" [translation] (The Financial ISET).

The young generation not only plays an "assigned role" due to the "economic nature" of the youth-state relationship ${ }^{19}$, but also through traditions rooted in the family. According to a 2016 study by the Friedrich-EbertStiftung Foundation, Georgian youth (aged 14-29) express the highest level of trust in their closest family members. As many as half of the respondents indicated very good contact with their family and joint decision making. It is also worth adding that $70 \%$ of the respondents were people who still lived with their parents. In Georgian culture, the older generation emphasizes the importance of caring for the family, especially parents. According to the 2019

19 According to a 2019 CRRC survey, 47\% of young people aged 18-35 believe that the state should be like an employer, and $46 \%$ believe that the state should be like a parent (Caucasus Barometer, 2019). 


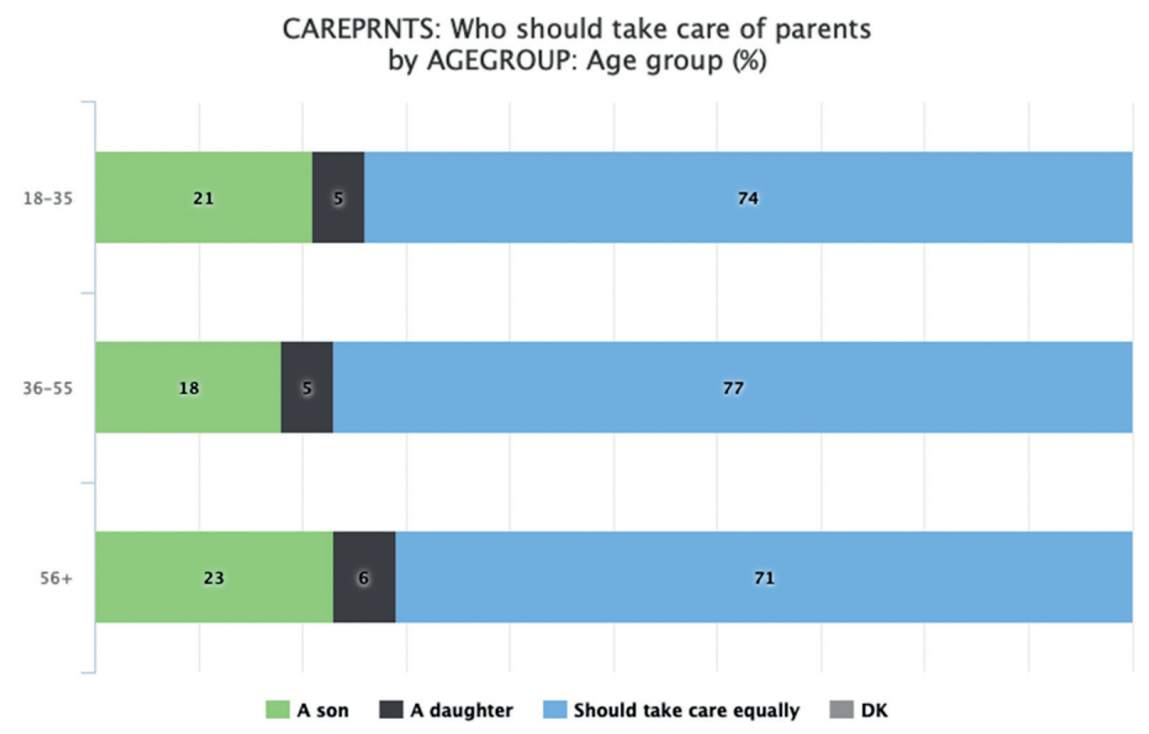

Figure 7. "Who Should Take Care of Parents" (by Age, in 2019)

Source: Caucasus Research Resource Center 2019.

CRRC research, all respondents aged 18-35 believed that children, both the daughter / s and son / s, should take care of their parents (Figure 7).

Gender plays an important role in the structure of the Georgian family. In the Georgian tradition, the man's task was to support the family, while the woman was to raise children and take care of the home. However, the role assigned to women in the context of social activity has never been a passive one - especially in the circles of families with a higher social status (Durglishvili, 1997). According to the Caucasus Barometer research from 2019, regarding the basic function that should be performed by a man according to traditional values, is, among others, earning money to support the household - 54\% of young people considered it to be the task of a man, and $45 \%$ that it was the role of both spouses (Figure 8). In addition, traditional values are also reflected in the age at which a woman should get married. According to $90 \%$ of young respondents, a woman should get married in the 18-25 age group, while only $5 \%$ considered the age of $26+$ to be right (Figure 9). 


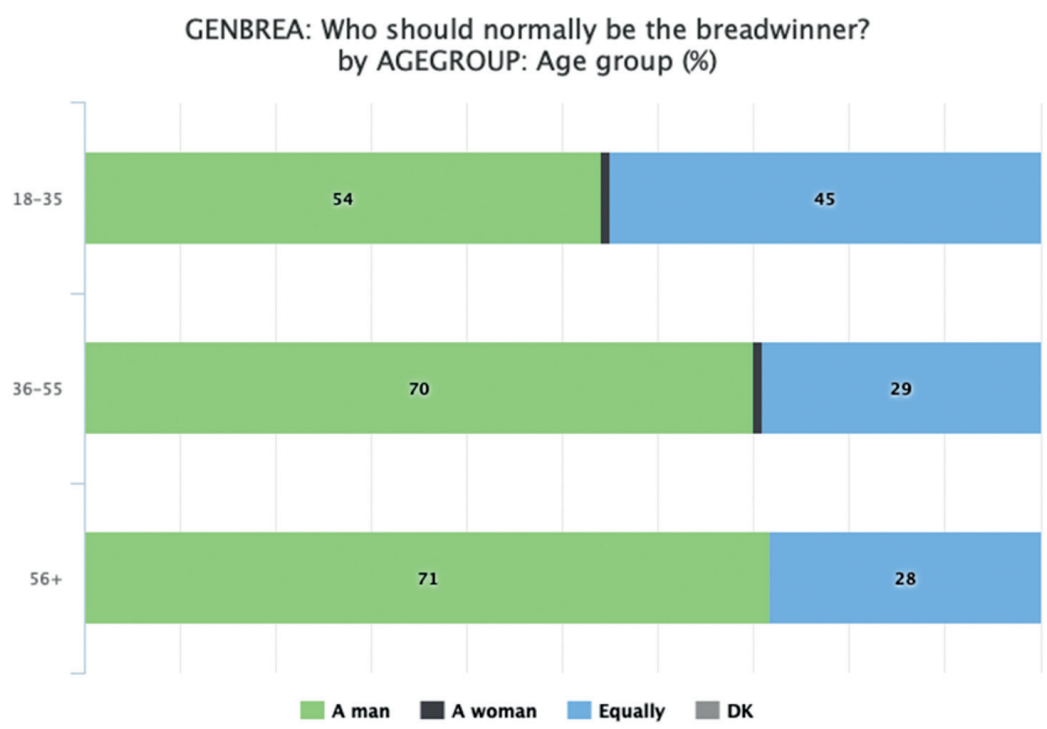

Figure 8. "Who Should Normally Be the Breadwinner?" (by Age, in 2019) Source: Caucasus Research Resource Center 2019.

ACCMARR: From what age is it acceptable for a woman to get married? by AGEGROUP: Age group (\%)

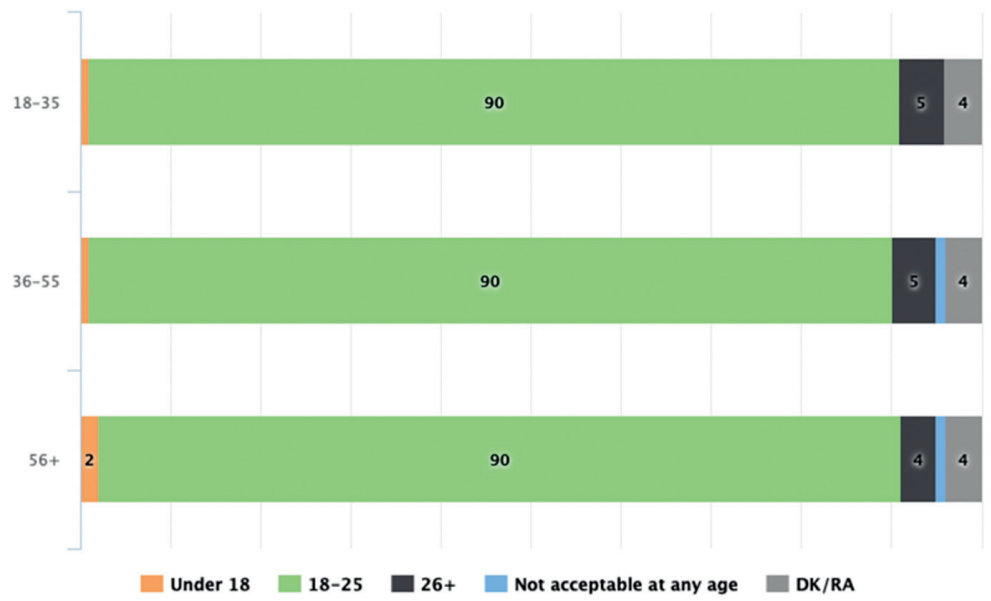

Figure 9. "From What Age Is It Acceptable for a Woman to Get Married?" (by Age, in 2019).

Source: Caucasus Research Resource Center 2019. 
The realization role as understood by young Georgians is mainly related to independence and success. According to the research of the FriedrichEbert-Stiftung Foundation from 2016, young people believe that they should first and foremost become financially independent from their family and achieve professional success not for the development of the Georgian economy, but because of their own aspirations. The respondents considered friends, religion, work and education their highest values, while the older generation appreciated family, politics and public life more. In the context of this study, young people were also asked about their satisfaction with life and fulfillment of these values. The results clearly showed that young people show more satisfaction with life and fulfillment of their values than older people (Friedrich-Ebert-Stiftung Foundation, 2016).

\section{Conclusions}

This analysis allows the author to conclude that the young generation of Georgians does not have a high social status, despite the fact that it is the future of Georgian society. The assumed factors that influence the social status of the group indicate that in the context of:

1. power-few young people participate in it, but the involvement of the younger generation in projects organized by the Parliament is visible. Participation in such endeavors can be the beginning of young people's participation in power;

2. money-young people do not constitute the group that earns the most in society; it is people aged $36-55$ who earn the most;

3. prestige-most young people have not started working or work in sectors in which the occupations do not belong to the "prestigious professions;"

4. education - the young generation aged $18-35$ is not the largest group in terms of university graduates. According to the data on current students, most of them are between 20 and 25 years old, while people over 35 are a definite minority;

5. health-young people assess their health as satisfactory in contrast to people over 36 years of age. 
KATARZYNA SKIERT-ANDRZEJUK, MA

Department of International Relations

Collegium Civitas

Plac Defilad 1, XII floor, 00-901 Warszawa

katarzyna.skiert@gmail.com

\section{Bibliography}

Association of Young Professionals in Energy of Georgia. Retrieved from: https://aypeg. ge/en/home/.

Bielajew, W., Szalin, D.N. (1979). Pojęcie roli w socjologii. In: J. Szmatka (ed.), Elementy mikrosocjologii (Wybór tekstów). Kraków: Uniwersytet Jagielloński.

Caucasus Research Resource Centers (CRRC). Retrieved from: https://caucasusbarometer.org/en/about/.

Domański, H. (2009). Stratyfikacja a system społeczny w Polsce. Ruch Prawniczy, Ekonomiczny i Socjologiczny, 2, 381-395.

Domański, H. (2004). Struktura społeczna. Warsaw: Wydawnictwo Naukowe Scholar.

Domański, H. (2012). Prestiż. Toruń: Wydawnictwo Naukowe Uniwersytetu Mikołaja Kopernika.

Durglishvili, N. (1997). Social Change and the Georgian Family. Tbilisi: Caucasian Institute for Peace, Democracy and Development

Friedrich-Ebert-Stiftung Foundation (2016). Generation in Transition: Youth Study 2016 - Georgia.

Global Teacher Status Index (2018). Retrieved from: https://www.varkeyfoundation.org/ media/4790/gts-index-9-11-2018.pdf.

Government of Georgia. Retrieved from: http://gov.ge/index.php?lang_id=ENG.

Herrmann, S. (2018, January 26). How to attract young people to choose agriculture over university. Georgian Journal. Retrieved from: https:/www.georgianjournal.ge/society/34135-how-to-make-young-people-choose-agriculture-over-university.html.

Homans, G.C. (1961). Social Behavior: its Elementary Forms. New York: Harcourt Brace \& World.

IDFI. Retrieved from: https://idfi.ge/en/contest_winner_youth_your_idea_for_open_ parliament.

ISET Policy Institute. Retrieved from https://iset-pi.ge/index.php/en/about-us/.

Marszałek-Kawa, J., Piechowiak-Lamparska, J., Ratke-Majewska, A., Wawrzyński, P. (red.). (2013). Constitutions of Selected Countries after the Transition from Authoritarian Regimes. Collection of Legal Acts. Vol. 1: Estonia, Georgia, Poland. Europejskie Centrum Edukacyjne. Toruń 2013.

Marszałek-Kawa, J., Plecka, D., Hołub, A. (red.). (2018). Social Security. Selected Aspects. Toruń: Wydawnictwo Adam Marszałek.

National Statistics Office in Georgia. Retrieved from: https:/www.geostat.ge/en/ modules/categories/646/higher-education. 
Olubiński, A. (1990). Rola społeczna a procesy socjalizacji i wychowania. Ruch prawniczy, ekonomiczny i socjologiczny, 2, 267-284.

Papava, V. (2002). Necroeconomics-The Theory of Post-Communist Transformation of an Economy. International Journal of Social Economics 29(10), 796-805.

Parliament of Georgia. Retrieved from: http://www.parliament.ge/en/.

Skarżyńska, K. (1981). Entry: potrzeby ludzkie. In: M. Bednarkiewicz, K. Łubczyk, E. Ługowska, J. Witecka (ed.), Encyklopedia organizacji i zarzadzania. Warszawa: Państwowe Wydawnictwo Ekonomiczne.

Spielberger, Ch.D. (2004). Encyclopedia of Applied Psychology. Tampa: University of South Florida.

Szmatka, J. (1980). Jednostka i społeczeństwo. O zależnościach zjawisk indywidualnych od społecznych. Warsaw: Państwowe Wydawnictwo Naukowe.

Trading Economics. Retrieved from: https://tradingeconomics.com/georgia/gdp-percapita.

The Financial, ISET Conference Focus on Young Generation's Role in Georgia. Retrieved from: https://www.finchannel.com/world/georgia/32584-.

Turner, J.H. (1985). Struktura teorii socjologicznej. Warsaw: Wydawnictwo Naukowe PWN.

UNHCR Report (2008). Retrieved from: www.unhcr.org/cgi-bin/texts/vtx/page?page= 49e486426\&submit=GO.

Waters, T., Waters, D. (2015). The Distribution of Power Within the Gemeinschaft: Classes, Stände, Parties. In: T. Waters (ed.), Weber's Rationalism and Modern Society (37-58). London: Palgrave Macmillan.

World Health Organization. Retrieved from: https://www.who.int/hia/tools/en/. Znaniecki, F. (1971). Nauki o kulturze. Warsaw: Wydawnictwo Naukowe PWN.

Znaniecki, F. (1984). Społeczne role uczonych. Warsaw: Wydawnictwo Naukowe PWN. 